INDONESIA ACCOUNTING JOURNAL

VOLUME 1, NUMBER 1, YEAR 2019

\author{
${ }^{1}$ Corresponding author \\ Jurusan Akuntansi \\ Fakultas Ekonomi dan Bisnis \\ Universitas Sam Ratulangi \\ Jl. Kampus UNSRAT \\ Manado, Indonesia, 95115 \\ E-mail : rifkasharen64@gmail.com \\ ${ }^{2,3}$ Jurusan Akuntansi \\ Fakultas Ekonomi dan Bisnis \\ Universitas Sam Ratulangi \\ Jl. Kampus UNSRAT \\ Manado, Indonesia, 95115 \\ Article info: \\ Received 16 October 2019 \\ Accepted 16 October 2019 \\ Available online 16 October 2019
}

Keywords: cost of goods sold; variable cost; electricity; postpaid meters; prepaid meters

JEL Classification: M41

DOI : http://doi.org/10.32400/iaj. 25743

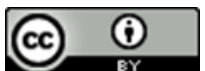

\section{Analisis perhitungan harga pokok penjualan meter pascabayar dan meter prabayar dalam menggunakan metode variable cost pada PT. PLN (Persero) ULP Manado Selatan○}

\author{
Rifka Sharen Rianto ${ }^{1}$ \\ Herman Karamoy ${ }^{2}$ \\ Anneke Wangkar ${ }^{3}$
}

\begin{abstract}
PT. PLN which a state-owned electricity company, in which this state-owned company has a meter product that helps the public to supply electricity, but in determining the selling price of the meter products orten experience problems because the selling price of the meter products often changes making customers often make complaints towards the company, for that the authors aim to examine the cost of goods sold in the company by using the variabel cost method, the study was conducted using a type of qualitative data to analyze accounting treatment and for the calculation of the author using quantitative data in the form of financial statements in order to calculate the calculation of cost of goods sold, after analysis by using the varibel cost method, the authors get the results under the calculation of variabel cost more profitable and not harming customers or costs that are not interested in calculating the cost of goods sold is the final result of the process of calculating the cost of goods sold of a postpaid meter product and a prepaid meter using the Variable cost method. There are 2 major groups in each sales process that will form the cost of goods sold report, namely production costs and non-production costs. PT. PLN (Persero) ULP Manado Selatan which is the object of research has a calculation of cost of goods in postpaid and prepaid meter products. In the calculation of the company's cost of goods sold is very high for the emphasis on the cost of products that cause very high cost problems, therefore according to the discussion to solve a problem in the calculation of cost of goods sold, the authors use the cost of goods sold calculation with the variable cost method. After re-calculation using the variable cost method the results show that lower than the calculation by the company where the cost of selling postpaid and prepaid meters is lower, the difference is caused by excess loading of costs that should not be included in cost of goods sold.
\end{abstract}

\section{Pendahuluan}

Perusahaan memiliki tujuan jangka pendek maupun jangka panjang. Tujuan utama yang ingin dicapai oleh perusahaan adalah pencapaian laba optimum. Pihak manajemen perusahaan harus merencanakan dan mengendalikan penjualan dan biaya agar laba optimum yang menjadi tujuan perusahaan dapat tercapai. Selain itu perusahaan pun dalam menjalankan operasinya dituntut bisa lebih optimal dan cepat dalam hal pencapaian tingkat pengembalian modalnya, karena dengan hal itu perusahaan dirasa mampu untuk terus beroperasi dan menjalankan aktivitasnya. Tingkat pengembalian modal perusahaan harus menajadi fokus karena penting bagi manajemen perusahaan, karena tidak sedikit perusahaan yang tutup operasinya karena ketidakmampuan perusahaan dalam mengembalikan modal apalagi untuk mendapatkan laba.Manajemen perusahaan 
harus cermat dalam hal ini karena perusahaan harus memperhatikan semua hal yang bisa mempengaruhi dalam tingkat pengembalian modal, baik penetuan harga pokok penjualan maupun efisiensi biaya dalam biaya operasionalnya. Penyusunan laporan laba rugi perusahaan mencakup penghitungan harga pokok penjualan, yang merupakan salah satu elemen laporan laba rugi. Perhitungan harga pokok penjualan yang terdiri dari persediaan awal, pembelian, beban angkut pembelian, retur pembelian, potongan pembelian, dan persediaan barang dagang akhir, harus dilakukan secara akurat, karena akan mempengaruhi laba atau rugi yang ditanggung perusahaan.

Penetapan harga jual sangat mempengaruhi kemampuan perusahaan dalam mempertahankan kelangsungan operasional, penetapan harga jual yang tidak tepat dapat mengakibatkan resiko kerugian perusahaan. Harga jual yang tepat yang ditetapkan perusahaan terhadap produk yang dijual, dapat meningkatkan daya saing dengan perusahaan competitor dan laba atas penjualan produk. Harga jual menggambarkan antisipasi perusahaan terhadap usaha untuk meningkatkan keuntungan perusahaan. Beberapa faktor yang harus dipertimbangkan dalam penetapan harga jual, yaitu : (1) berapa besar keuntungan yang diharapkan; (2) stabilitas penjualan; (3) stabilitas keuntungan; (4) berapa resiko kebangkrutan yang di hadapi; dan (5) biaya penjualan dan laba perusahaan. Penetapan harga jual harus mempertimbangkan sumber dan biaya, agar diperoleh harga jual yang optimal. Situasi dan kondisi tertentu yang tidak terduga, sering dihadapi perusahaan yang mempengaruhi penetapan harga jual. Kenaikan harga bahan baku dan penolong harus diantisipasi perusahaan dengan penyesuaian harga jual produk, agar kerugian bisa dihindari. Tingkat laba yang diperoleh perusahaan ditentukan oleh pengendalian proses dan luas produksinya, serta penentuan harga jual produk.

Perhitungan harga pokok penjualan menjadi faktor terpenting dalam penentuan harga jual produk, jika harga pokok karena perhitungan harga pokok penjualan yang terlalu tinggi akan menyebabkan harga jual yang tinggi pula. Harga jual produk yang tinggi akan mempengaruhi daya beli konsumen dan selanjutnya mengurangi permintaan akan produk tersebut. Penurunan permintaan produk yang disebabkan oleh harga produk yang tinggi, harus diantisipasi oleh perusahaan dengan meningkatkan pelanggan baru, jika tidak akan mengakibatkan penurunan laba perusahaan dan penurunan tingkat produksi. Penurunan permintaan barang atau jasa dari konsumen harus diimbangi oleh kemampuan dari bagian pemasaran untuk mencari pelanggan baru karena akan mengakibatkan produksi dan laba perusahaan menurun karena harga pokok penjualan meningkat akibat dari biaya tetap. PT.PLN (Persero) Unit Layanan Pelanggan (ULP) Manado Selatan merupakan perusahaan yang bergerak di bidang penyediaan listrik bagi masyarakat. Selaku perusahaan milik Negara yang menangani masalah kepentingan listrik di Indonesia yang memberikan jumlah pasokan listrik kepada masyarakat dalam jumlah yang sangat besar, PT.PLN (Persero) ULP Manado Selatan dituntut memberikan pelayanan yang maksimal. Namun masalah sering timbul dalam kegiatan operasional pelayanan, seperti kesalahan administrasi maupun gangguan teknis serta penentuan harga jual produk yang selalu berubah-ubah. Hal ini membuat konsumen melakukan pengeluhan terhadap kesalahan-kesalahan tersebut.

\section{Tinjauan pustaka}

Pengertian akuntansi. Menurut Kieso (2016:2), akuntansi terdiri dari tiga kegiatan yang mendasar yaitu identifikasi, pencatatan dan pengkomunikasian kejadian ekonomi suatu organisasi kepada pihak yang berkepentingan. Kartikahadi (2016:3) menyatakan bahwa akuntansi adalah suatu sistem informasi keuangan, yang memiliki tujuan untuk menghasilkan dan melaporkan informasi yang relevan bagi pihak yang berkepentingan. 
Pengertian harga pokok penjualan. Supriyono dalam Macpal (2015:1497) menyatakan bahwa harga perolehan atau harga pokok adalah jumlah yang dapat diukur dalam satuan uang dalam bentuk kas yang dibayarkan, atau nilai aktiva lainnya yang diserahkan/dikorbankan, atau nilai jasa yang diserahkan/dikorbankan,atau hutang yang timbul, atau tambahan modal. Purba dalam Widayawati (2015:194) menyatakan bahwa harga jual adalah sejumlah nilai yang ditukar oleh konsumen dengan manfaat dan memiliki atau menggunakan produk atau jasa yang nilainya ditetapkan oleh pembelian dan penjual untuk satu harga yang sama terhadap semua pembeli. Suwardjono (2016:233) menyatakan pendapat yang berbeda yaitu makna harga pokok penjualan sebenarnya adalah harga dari pokok penjualan yang bermakna barang yang terjual. Namun pokok tiba-tiba berubah fungsinya menjadi penjelas harga sehingga timbul harga pokok. Jadi harga pokok merupakan istilah yang sangat rancu karena diturunkan dari istilah yang rancu lagi yaitu harga pokok penjualan. Istilah beban pokok penjualan makin rancu lagi, beban pokok penjualan berarti pengurangan pokok penjualan, hal ini berarti biaya administrasi dan penjualan dipandang tidak pokok dan ini bertentangan dengan praktik bisnis modern saat ini. Mungkin saja harga pokok penjualan dipakai sebagai kata cost of sales. Akan tetapi cost of sales memberi kesan sebagai kas dalam rangka mendatangkan penjualan.

Elemen harga pokok penjualan. Mulyadi (2016:197) menyatakan bahwa struktur dasar harga pokok penjualan terdiri dari 3 elemen besar yaitu : persediaan (inventory), tenaga kerja langsung (direct labor cost) dan overhead cost.

a. Persediaan (inventory) dalam perusahaan dagang atau jasa, elemen persediaan hanya terdiri dari persediaan barang jadi saja atau yang dikenal inventory. Persediaan adalah besarnya persediaan yang terjual maka perlu mengetahui unsur-unsur persediaan antara lain: (1) persediaan awal adalah persediaan yang tersedia pada awal suatu periode atau tahun buku berjalan; (2) pembelian adalah cost yang terjadi sehingga besarnya nilai pembelian yang di akui hanya sebesar cost yang timbul saja; dan (3) persediaan akhir adalah persediaan pada akhir suatu periode atau tahun buku berjalan; dan (4) persediaan tersedia untuk dijual adalah harga pokok pembelian dari seluruh barang yang dibeli selama periode akuntansi.

b. Tenaga kerja langsung (direct labor cost) adalah upah yang dibayarkan kepada tenaga kerja langsung terlibat pada proses pengolahan barang dagangan. Dikatakan direct labor cost hanya jika besarnya upah satuan atau upah harian/jam.

c. Overhead cost adalah cost yang timbul selain dari kedua elemen diatas, yang biasanya disebut dengan indirect cost, jenis tentu saja bervariasi tergantung jenis usaha, skala usaha dan jenis sumberdaya yang dipakai oleh perusahaan.

Metode penentuan harga. Widyawati (2015:195) menyatakan bahwa perusahaan menentukan harga jual produknya dengan tiga dasar perimbangan yaitu biaya produksi, suplai perusahaan dan harga persaingan. Penentuan harga berdasarkan biya produksi. Pada strategi ini perusahaan menentukan harga untuk sebuah produk dengn mengestimasi biaya per unit untuk memproduksi produk tersebut dan menambahkan suatu kenaikkan.

Tujuan penetapan harga jual. Widyawati (2015 : 197) menyatakan bahwa ada beberapa tujuan penetapan harga jual yaitu : (1) untuk mendukung strategi pemasaran secara keseluruhan; (2) mendapatkan keuntungan sebesar-besarnya dengan menetapakan harga yang kompetitif; (3) mempertahankan perusahaan dari marjin keuntungan yang didapatkan perusahaan akan digunakan untuk biaya operasional perusahaan; (4) menggapai ROI perusahaan pasti menginginkan baik modal dari investasi yang ditanam pada perusahaan; (5) menguasai pangsa pasar dengan menetapkan harga lebih rendah dibandingkan produk 
pesaing; dan (6) mempertahankan status ketika perusahaan memilik pasar tersendiri.

Persediaan dalam harga pokok penjualan. Juan dan Esra (2015:152) menyatakan bahwa penentuan nilai persediaan di akhir tahun buku akan berpengaruh secara langsung terhadap penentuan harga pokok penjualan selama satu tahun tersebut. Hal ini dikarenakan nilai persediaan akhir dan harga pokok penjualan didapatkan dari hasil alokasi sejumlah tetap biaya barang yang tersedia untuk dijual.

Metode biaya variable (variable cost). Mulyadi (2015:233) menyatakan bahwa metode variable cost yaitu pemisahan antara biaya tetap dengan biaya variabel sehingga dapat menyajikan informasi sehubungan dengan pengambilan keputusan jangka pendek. Biaya variabel merupakan biaya yang berubah secara linier sesuai dengan volume output operasi perusahaan. $V$ ariable cost dapat di hitung dari penurunan rumus menghitung biaya total yaitu Total Cost $=$ Fix Cost + Variable Cost atau Variable Cost $=$ Total Cost - Fix Cost .

Penelitian terdahulu. Sari (2014) menganalisis efektivitas pengendalian biaya produksi,untuk meningkatkan efektivitas akuntansi pertanggung jawaban biaya produksi, metode yang dipilih adalah metode kuantitatif dan berdasarkan hasil penelitian lebih meningkatkan efektivitas dalam biaya produksi untuk pertanggung jawaban. Evelyn (2018) menganalisis pengaruh perubahan penjualan dalam profitability untuk melihat perubahan penjualan dalam profitability. Berdasarkan hasil penelitian bahwa profitability dalam perubahan penjualan sedikit tidak menguntungkan menggunakan metode penelitian kualitatif. Wati (2014) menganalisis harga pokok produksi dalam kaitannya dengan penentuan harga jual untuk pencapaian target laba untuk mencapai harga pokok produksi dalam penentuan harga jual agar laba tercapai. Berdasarkan hasil penelitian bawah harga pokok dalam penentuan harga jual belum tercapai dalam target laba menggunakan metode penelitian kualitatif. Maridiana
(2016) menganalisis perhitungan harga pokok penjualan rumah pada PT. Prima Indah Perwita guna penggolongan biayabiaya yang mempengaruhi harga pokok penjualan unit rumah. Hasil penelitian menujukan bawah penggolongan biaya rumah perunitdalam penjualan harga pokok belum tergolongkan dengan baik. Noviana (2015) menganalisis harga pokok jasa kamar rawat inap rumah sakit menggunakan metode variable cost studi kasus pada RSUP Dr. Soeradji Tirtonegoro untuk mengetahui apakah harga pokok jasa kamar rawat inap RSUP Dr. Soeradji Tirtonegoro ada perbedaan dengan harga pokok jasa menurut metode biaya variabel. Hasil penelitian menunjukkan bahwa adanya perbedaan antara harga pokok jasa kamar rawat inap RSUP Dr. Soeradji dengan harga pokok jasa kamar inap menurut metode biaya variabel.

\section{Metode penelitian}

Jenis, sumber, dan metode
pengumpulan data
Jenis data. Kuncoro $(2013: 90)$ data merupakan sekumpulan informasi yang diperlukan untuk mengambil keputusan. Jenis data terbagi atas dua yaitu : (1) data kuantitatif yaitu data yang mengandung angka atau bilangan yang digunakan dalam menjelaskan berbagai gambaran dan peristiwa sehubungan dengan pelaksanaan penelitian; dan (2) data kualitatif yaitu data kualitatif adalah data-data yang bersifat deskriptif yang menggambarkan tanggapan responden. Penelitian ini menggunakan data kualitatif sebagai dasar untuk menganalisis perlakuan akuntansi terhadap harga pokok Penelitian penjualan pada PT.PLN (persero) ULP Manado selatan. Adapun data kuantitatif dalam bentuk laporan keuangan pada tahun 2018 untuk menghitung harga pokok penjualan produk meter pascabayar dan meter prabayar pada PT.PLN (persero) ULP Manado Selatan.

Sumber data. Sumber data dalam penelitian ini adalah: (1) sumber data primer yaitu sumber data yang secara langsung memberikan data kepada pengumpulan data. Sugiyono (2014:308) menyatakan bahwa 
data primer ini berupa catatan hasil wawancara yang diperoleh melalui wawancara yang penulis lakukan. Selain itu, penelitian ini juga melakukan observasi lapangan dan mengumpulkan data dalam bentuk catatan tentang situasi dan kejadian di lapangan; dan (2) sumber data sekunder yang merupakan sumber data yang tidak memberikan informasi secara langsung kepada pengumpulan data. Data sekunder ini dapat berupa hasil pengolahan lebih lanjut dari data primer yang disajikan dalam bentuk lain atau dari orang lain. Sugiyono (2014:131) menyatakan bahwa data ini digunakan untuk mendukung informasi dari data primer yang diperoleh baik wawancara, maupun dari observasi langsung ke lapangan. Penelitian ini juga menggunakan data sekunder hasil dari studi pustaka. Dalam studi pustaka, penelitian ini menggunakan literatur-literatur yang dapat menunjang penelitian, yaitu literatur-literatur yang berhubungan dengan penelitian ini. Sumber data yang digunakan dalam penelitian ini adalah data primer dan data sekunder. Data primer berupa data hasil wawancara yang dilakukan kepada PT. PLN (Persero) ULP Manado Selatan secara langsung. Sedangkan data sekunder diperoleh dari dokumen-dokumen perusahaan berupa catatan dan laporan perusahaan baik yang dipublikasikan maupun yang tidak dipublikasikan.

Metode pengumpulan data. Dalam penelitian ini, digunakan beberapa metode dalam mengumpulkan data yaitu :

a. Wawancara. Metode wawancara yaitu penulis melakukan interaksi dan komunikasi untuk mendapatkan informasi dengan cara bertanya langsung kepada narasumber di PT.PLN (persero) ULP Manado Selatan. Sehingga penulis mendapatkan keterangan data yang diperlukan dalam penelitian ini melalui wawancara. Metode ini dilaksanakan untu mengetahui kondisi internal perusahaan. adapun pertanyaan yang di ajukan berkaitan dengan penelitian ini adalah: (1) bagaimana proses penjualan meter pascabayar dan meter prabayar dalam PT. PLN (Persero) ULP Manado
Selatan?; (2) bagaimana cara membedakan produk meter pascabayar dan produk meter prabayar dalam segi penjualan pada PT.PLN (persero) ULP Manado Selatan; (3) bagaimana kegiatan pemasaran pada PT. PLN (Persero) ULP Manado Selatan?; dan (4) bagaimana Perhitungan harga pokok penjualan meter pascabayar dan meter prabayar dalam PT.PLN (persero) ULP Manado Selatan.

b. Dokumentasi. Melakukan reviu terhadap dokumen-dokumen instansi yang relevan, berupa laporan keuangan, cara perhitungan harga pokok penjualan, serta mempelajari referensi yang terkait dengan penelitian yang dilakukan.

Metode dan proses analisis data. Setelah data-data diperoleh, maka data tersebut selanjutnya diolah kemudian dilakukan analisis. Metode yang di gunakan dalam penelitian ini adalah analisis deskriptif komparatif dengan cara mendeskripsikan atau menggambarkan keadaan objek penelitian yang sesungguhnya untuk mengetahui dan menganalisis tentang permasalahan yang dihadapi oleh objek penelitian kemudian dibandingkan dengan standar yang ada pada saat itu untuk selanjutnya dideskripsikan bagaimana PT. PLN (persero) ULP Manado Selatan memperlakukan perhial yang berkaitan dengan Perhitungan Harga Pokok Penjualan dalam mendapatkan keuntungan untuk penjualan meter pascabayar dan prabayar. Adapun tahapan-tahapan analisis dan pembahasan yang digunakan dalam penelitian ialah memberikan gambaran tentang landasan operasional yang di gunakan oleh PT. PLN (Persero) ULP Manado Selatan dan menganalisis perlakukan akuntansi atas perhitungan harga pokok penjualan yang diterapkan oleh PT. PLN (Persero) ULP Manado Selatan. Berikut ini tahapan-tahapan dalam proses analisis: (1) mengumpulkan data di PT. PLN (Persero) ULP Manado Selatan dalam melakukan perhitungan harga pokok penjualan; (2) proses penjualan meter pascabayar dan meter prabayar; (3) perbedaan meter pascabayar dan meter 
prabayar dalam segi penjualan; (4) menganalisis perhitungan harga pokok penjualan di PT. PLN (Persero) ULP Manado Selatan; (5) menganalisis perhitungan harga pokok penjualan dengan metode Variabel cost dengan rumus: Total Cost $=$ Fix Cost + Variable Cost atau Variable Cost $=$ Total Cost - Fix Cost; (6) setelah menganalisis perhitungan harga pokok penjualan dengan menggunakan metode variable cost. Dilakuan perbandingan dalam menentukan manakah yang lebih menguntungkan perhitungan harga pokok penjualan menggunakan metode perusahaan atau menggunakan metode variabel cost, dan (7) menarik kesimpulan dan saran dari hasil perbandingan perhitungan harga pokok penjualan yang dilakukan PT.PLN (persero) ULP Manado Selatan dengan hasil perhitungan harga pokok penjualan menggunakan metode variable cost.

\section{Hasil penelitian dan pembahasan}

Gambaran umum objek penelitian. PT. PLN (Persero) Unit Layanan Pelanggan (ULP) Manado Selatan merupakan perusahaan Negara yang menyediakan listrik bagi masyarakat. Perusahaan ini telah banyak memberikan kontribusi yang besar dalam memasok kebutuhan listrik untuk masyarakat. Selaku perusahaan milik Negara yang menangani masalah kepentingan listrik di Indonesia yang memberikan jumlah pasokan listrik kepada masyarakat dalam jumlah yang sangat besar, tentunya PT.PLN (persero) ULP Manado Selatan dituntut memberikan layanan maksimal sebagai upaya dalam memberikan kualitas pelayanan yang maksimal untuk kepentingan dan kemajuan bangsa. Namun dalam operasional pelayanan tidak selamanya seperti yang kita harapkan, kesalahan administrasi maupun gangguan teknis serta penentuan harga jual produk yang selalu berubah-ubah yang membuat konsumen melakukan pengeluhan terhadap kesalahan-kesalahan tersebut. Adapun kebijakan mutu yang ditetapkan oleh PT. PLN (Persero) ULP Manado Selatan, dimana manajemen dan seluruh karyawan/karyawati PT. PLN Cabang
Manado bertekad untuk selalu memenuhi kepuasan pelanggan melalui: (1) peningkatan pelayanan, pendapatan, efesiensi, dan kinerja PT. PLN (Persero) ULP Manado Selatan; (2) PT. PLN (Persero) ULP Manado Selatan menerapkan sistem manajemen mutu ISO 9001:2008 secara efektif dan perbaikan yang berkesinambungan sesuai persyaratan dan peraturan perundang-undangan yang berlaku; dan (3) komitmen PT. PLN (Persero) ULP Manado Selatan terhadap peningkatan "Tingkat Mutu Pelayanan" dengan didukung dengan sumber daya manusia yang berkompetensi dan profesional serta pemanfaatan teknologi informasi yang terintergrasi. Kebijakan mutu ini dikomunikasikan dalam lingkungan PT. PLN (Persero) ULP Manado Selatan untuk mendapatkan kesetaraan pemahaman dan selalu ditinjau terus menerus melalui "review management" agar mencapai sasaran yang sesuai dengan komitmen perusahaan.

\section{Hasil Penelitian}

Proses penjualan meter pascabayar dan meter prabayar. Dalam proses penjualan meter pascabayar dan meter prabayar mempunyai beberapa proses yang harus dilakukan oleh pelanggan, untuk kebutuhan masing-masing pelanggan seperti, permintaan pasang baru, permohonan tambah daya dan perubahan daya. Dalam permintaan-permintaan tersebut ada proses yang harus dilakukan oleh pelanggan dan perusahaan. Pelanggan mendatangi PLN untuk melakukan permohonan pasang baru meter setelah melakukan permohonan pelanggan melakukan pengisian data untuk permohonan, kemudian setelah melakukan pengisian data pelanggan menerima nomor registrasi untuk pembayaran, setelah melakukan pembayaran pelanggan menandatangani Surat Perjanjian Jual Beli Tenaga Listrik (SPJBTL) dan setelah itu Petugas PLN melakukan Aktivasi Kwh meter setelah di aktivasi maka dibuatkanlah oleh petugas surat Perintah Kerja (PK) dan Berita Acara (BA) lalu petugas melakukan pemasangan meter kepada pelanggan yang melakukan permohonan, dalam proses permohonan tambah daya dan perubahan 
daya mempunyai proses yang sama seperti yang di gambarkan. Menurut Supriyono dalam Macpal (2015 : 1497), harga perolehan atau harga pokok adalah jumlah yang dapat diukur dalam satuan uang dalam bentuk kas yang dibayarkan, atau nilai aktiva lainnya yang diserahkan/dikorbankan, atau nilai jasa yang diserahkan/dikorbankan,atau hutang yang timbul, atau tambahan modal".Sebagaimana yang telah dijelaskan bawa PT.PLN (Persero) ULP Manado Selatan adalah perusahaan yang bergerak dibidang distribusi yaitu menjual atau penyuplai aliran listrik dengan menggunakan meter pascabayar dan prabayar akan tetapi produk atau meter pascabayar dan prabayar yang telah di pasang atau dimiliki oleh pelanggan bukanlah milik pelanggan tetapi masih milik PLN karena pelanggan hanya membayar biaya penyambungan sesuai dengan kapasitas meter yang mereka beli, Karena setiap harga penyambungan berbeda sesuai besarnya meter pascabayar dan meter prabayar.

Perhitungan harga pokok penjualan pada PT. PLN (Persero) ULP Manado Selatan. PT.PLN (Persero) ULP Manado Selatan dalam memperhitungkan harga pokok penjualan masih sangat sederhana, dimana perusahaan memperhitungkan seluruh biaya-biaya dalam harga pokok penjualan, meliputi persediaan barang, biaya pembelian penyambungan, barang tersedia terjual ,persediaan akhir barang adapun perhitungan untuk biaya tenaga kerja langsung yang di keluarkan oleh PLN untuk pemasangan meter serta di aktivasi. Dalam penelitian ini, sesuai data yang diterima penulis dari perusahaan, maka penulis menggunakan data biaya tahun 2018 yang akan dijadikan sampel. Berikut ini merupakan metode perhitungan harga pokok penjualan oleh PT. PLN (persero) ULP Manado Selatan berdasarkan biaya yang telah disusun terlebih dahulu sesuai dengan biaya riil yang terjadi selama periode 1 Januari s/d 31 Desember 2018 bisa di lihat pada Tabel 1.
Tabel. 1 Perhitungan harga pokok penjualan

PT. PLN (Persero) ULP Manado Selatan

periode 1 Januari s/d 31 Desember 2018

\begin{tabular}{|c|c|}
\hline Keterangan & $\begin{array}{r}\text { PLN ULP Manado } \\
\text { Selatan }\end{array}$ \\
\hline Biava Tetap & Rp. 16.910.941.345 \\
\hline Biava Variabel & Rp. 9.010.842.023 \\
\hline $\begin{array}{l}\text { Total Harga Pokok } \\
\text { Penjualan }\end{array}$ & Rp. 24.148.388.515 \\
\hline Total Kuantitas Meter & Rp. 723.649.209 \\
\hline $\begin{array}{l}\mathrm{HPP} / \text { Meter (Rp/Meter } \\
\text { jual) }\end{array}$ & Rp. 3.337 \\
\hline
\end{tabular}

Sumber: Data PT. PLN (Persero) ULP Manado Selatan 2019

Tabel 2 menunjukkan perhitungan harga pokok penjualan dengan metode variable cost menghasilkan harga pokok yang lebih rendah untuk penjualan meter. Dapat terlihat bahwa hasil perhitungan kembali pada harga pokok penjualan dengam menggunakan metode variable cost telah mencerminkan biaya meter dalam proses Penjualan dimana perhitungan tersebut mencatat biaya distribusi yang benar-benar terjadi pada setiap proses penjualan. Hal ini dapat dipahami karena metode variable cost berusaha untuk menyeimbangkan biaya meter pascabayar dan meter prabayar dan seluruh biaya produksi dan non produksi dengan melakukan identifikasi terhadap produk yang di jual oleh PLN dengan demikian informasi yang dihasilkan dari perhitungan harga pokok produksi dengan metode variable cost sangat diperlukan oleh manajemen dalam usaha distribusi meter pascabayar dan meter prabayar dalam penyambungan energy listrik. Metode perhitungan harga pokok penjualan yang dilakukan oleh PLN selama ini menghasilkan harga pokok penjualan yang tinggi bila di bandingkan dengan harga pokok penjualan yang dihitung dengan metode variable cost.

Tabel 2. Perbandingan perhitungan harga pokok penjualan

antara perusahaan dengan metode variable cost

\begin{tabular}{lrrrr}
\hline Keterangan & $\begin{array}{r}\text { HPP } \\
\text { Cost }\end{array}$ & Variable & $\begin{array}{l}\text { PLN } \\
\text { Selatan }\end{array}$ \\
\hline Total Harga & Rp. & Rp. \\
Pokok Penjualan & 23.521 .340 .155 & 24.148 .388 .515 \\
Total Kuantitas & Rp. 723.649 .209 & Rp. 723.649.209 \\
Meter & & \\
HPP/ Meter & Rp. 3.205 & Rp. 3.33 \\
Rp/Meter jual) & & \\
\hline \multicolumn{2}{l}{ Sumber: Data PT. PLN (Persero) ULP Manado Selatan 2019 }
\end{tabular}




\section{Kesimpulan}

Berdasarkan hasil penelitian maka dapat ditarik kesimpulan berikut: (1) perhitungan harga pokok penjualan (HPP) pada PT. PLN (Persero) ULP Manado Selatan Analisis atas harga pokok penjualan PT. PLN (Persero) ULP Manado Selatan menunjukkan nilai yang belum efisien disebabkan terdapat pembebanan biaya yang membuat HPP menjadi naik dan menyebabkan kerugian terhadap pelanggan dan terhadap PT. PLN (Persero) ULP Manado Selatan. Perhitungan HPP dalam menggunakan metode variable cost, penelitian ini menggunakan rumus (Total Cost $=$ Fix Cost + Variable Cost atau Variable Cost $=$ Total Cost - Fix Cost) guna mendapatkan hasil yang maksimal; dan (2) hasil yang di dapatkan dengan dilakukan perbandingan mendapatkan hasil bawah perhitungan HPP dalam menggunakan metode variable cost lebih menguntungkan karena secara teori, dalam perhitungan harga pokok penjualan yang digunakan oleh perusahan kurang sesuai karena adanya kelebihan pembebanan biaya terhadap harga pokok penjualan meter pascabayar dan meter prabayar. Hasil dari perhitungan harga pokok penjualan perusahaan yang di dapatkan sejumlah Rp.3.337/meter penjualan dan perhitungan harga pokok penjualan meter pascabayar dan meter prabayar dalam menggunakan metode variable cost sejumlah Rp.3.205/meter penjualan maka perhitungan menggunakan metode variable cost menghasilakan harga pokok meter lebih rendah untuk penjualan meter pascabayar dan meter prabayar. Kuranganya pengelolaan administrasi yang dilakukan oleh perusahaan untuk menekan biaya produk meter pascabayar dan prabayar yang menyebabkan harga penyambungan energy listrik sangat tinggi dan tarif listrik pun meningkat. Terdapat beberapa hal yang dapat di jadikan pertimbangan bagi pihak perusahaan yaitu PT.PLN (persero) ULP Manado Selatan, yaitu: (1) PT. PLN (Persero) ULP Manado Selatan agar dapat lebih efisien dalam melaksanakan pengelolaan penjualan meter pascabayar dan meter prabayar. Hal ini agar pelanggan tidak merasa dibebankan atas biaya penyambungan dalam bentuk produk meter pascabayar dan meter prabayar; dan (2) PT. PLN (Persero) ULP Manado Selatan agar dapat lebih meningkatkan kualitas produk yang dikeluarkan agar tidak mengalami kerugian bagi perusahaan dan bagi pelanggan.

\section{Daftar pustaka}

Gerung, E. (2018). Pengaruh perubahan penjualan diskon pada pembelian aset intensity profitability (Survei pada Mahasiswa Fakultas Ilmu Administrasi Universitas Tarumanagara Angkatan 2013/2014 Konsumen Traveloka). Skeripsi. Universitas Tarumanagara Jakarta. Indonesia.

Kartikahadi, H. (2016). Akuntansi Biaya. Edisi II Yogyakarta ; BPFE.

Juan, N. E., \& Esra, T. W. (2015). Standar Akuntansi Keuangan Edisi II Yogyakarta: BPFE.

Kieso, et.al. (2016). Intermediate Accounting, 14th Edition. Asia. : John Wiley \& Sons Inc.

Kuncoro.(2014). A study on acconting of tranfer princing and effect on taxation. Yogyakarta: Liberty

Macpal. (2016). Pengantar Akuntansi 1. Jakarta; Lembaga Penerbit Fakultas Ekonomi (LPPE) Universitas Indonesia.

Mardina. (2016). Analisis perhitungan harga pokok penjualan rumah pada PT. Prima Indah Perwita. Unversitas 17 Agustus 1945. Samarinda

Mulyadi. (2016). Akuntansi Biaya. Edisis 5 Jogyakarta: STIE YKPN.

Noviana. (2016). Analisis perhitungan harga pokok produksi susu poang dengan menggunakan metode Variabel Cost. Fakultas Ekonomi dan Manajemen Institut Pertanian.

Sanusi, A. (2014). Metodologi Penelitian Bisnis. Jakarta: Salemba Empat.

Sari. (2012). Analisis efektivitas pengendalian biaya produksi pada PT. Daur Ulang Sejahtera DSA. Dibandar Lampung. Skripsi. Universitas Bandar Lampung. Indonesia

Suwardjono. (2016). Teori Akuntansi: Perekayasaan Pelaporan Keuangan edisi III. Yogyakarta: BPFE

Warindrani. (2006). Akuntansi Manajemen, Edisi 1. Yogyakarta: Graha Ilmu.

Wati. (2014). Perhitungan Harga Pokok Produksi Dengan Menggunakan Metode Variable Cost dalam menentukan harga jual pada Kertina Shome Industri. (Survei pada Mahasiswa Akuntansi Keuangan Fakultas Ilmu Akuntansi Universitas Sumatera Utara). Skripsi. Universitas Sumatera Utara. Medan. Indonesia.

Widyawati. (2015). Akuntansi Biaya. Jakarta Selatan: Salemba Empat. 